\title{
IMPLEMENTASI MATERI SEJARAH LOKAL GERAKAN SOSIAL MESSIANISTIK DAN NATIVISME DI BANTEN MELALUI PENDEKATAN SAINTIFIK
}

\author{
Rikza Fauzan \\ Jurusan Pendidikan Sejarah, Universitas Sultan Ageng Tirtayasa \\ rikza.fauzan@untirta.ac.id
}

Abstract: Less interest in history lessons becomes a serious problem for education in Indonesia. The lesson of history actually serves as a characteristic form of the younger generation. This issue certainly describes the conditions that are prone to the survival of the nation and state of Indonesia. The Government is quick to respond to this problem by positioning history subjects as a key element in the Curriculum 2013. In the Curriculum 2013, the lesson of history is divided into two parts: History of Indonesia and History (Development of the Social Sciences). This resulted in a change in the hours of history subjects that more than doubled from before. The 2013 curriculum in its learning uses a scientific approach (scientific appoach) which includes components: observing, asking, trying, processing, presenting, summarizing, and creating. This allows more freedom of various historical materials taught to learners. One of them is local history material. Local history is a history that occurs in spatial (space) certain locality in a community with temporal (time). This event can occur simultaneously with national history. The local history of the social movement in Banten is one of the lesser-cared material as an integral part of the periodic struggle for independence in National History. Learning history with local history material is more easily understood learners, because it can see firsthand the real life reality in the nearest environment. Between learners, contemporary life and historical events will form an identity bond that facilitates the inheritance of values. The inheritance of values in the events of Kyai's social movements and farmers in Banten would be easier in shaping positive values, such as patriotism and love of the homeland.

Abstrak: $\quad$ Kurang diminatinya pelajaran sejarah menjadi satu masalah serius bagi pendidikan di Indonesia. Pelajaran sejarah sesungguhnya sangat berfungsi sebagai pembentuk karakter generasi muda. Masalah ini tentu menggambarkan kondisi yang rawan bagi keberlangsungan kehidupan bangsa dan negara Indonesia. Pemerintah dengan cepat merespons masalah ini dengan cara memposisikan mata pelajaran sejarah sebagai unsur utama yang diperhatikan dalam Kurikulum 2013. Pada Kurikulum 2013, pelajaran sejarah terbagi menjadi dua bagian: Sejarah Indonesia dan Sejarah (Peminatan Ilmu-ilmu sosial). Hal ini menyebabkan terjadinya perubahan jam mata pelajaran sejarah yang meningkat lebih dari dua kali lipat dari sebelumnya. Kurikulum 2013 dalam pembelajarannya menggunakan pendekatan ilmiah (scientific appoach) yang didalamnya mencakup komponen: mengamati, menanya, mencoba, mengolah, menyajikan, menyimpulkan, dan mencipta. Hal ini memungkinkan lebih leluasanya berbagai materi sejarah diajarkan kepada peserta didik. Salah satu diantaranya ialah materi sejarah lokal. Sejarah lokal merupakan sejarah yang terjadi dalam hal spasial (ruang) lokalitas tertentu dalam suatu komunitas masyarakat dengan temporal (waktu). Kejadian ini dapat terjadi secara bersamaan dengan sejarah nasional. Sejarah lokal mengenai gerakan sosial di Banten menjadi satu diantara materi yang kurang diperhatikan sebagai bagian integral dalam periodesasi perjuangan kemerdekaan pada Sejarah Nasional. Pembelajaran sejarah dengan materi sejarah lokal lebih mudah dipahami peserta didik, karena dapat melihat secara langsung realitas kehidupan sesungguhnya di lingkungan terdekat. Antara peserta didik, kehidupannya masa kini, dan peristiwa sejarah akan membentuk sebuah ikatan identitas yang memudahkan pewarisan nilai-nilai. Pewarisan nilai dalam peristiwa gerakan sosial Kyai dan petani di Banten akan lebih mudah dalam membentuk nilai-nilai positif, seperti patriotisme dan cinta tanah air.

Kata Kunci: $\quad$ kurikulum 2013, pendekatan saintifik, sejarah lokal

\section{PENDAHULUAN}

Permasalahan yang terjadi di lapangan dalam pembelajaran sejarah ialah anggapan yang mengatakan bahwa pembelajaran sejarah adalah pembelajaran yang menjenuhkan, membosankan, model pembelajaran yang monoton, dan kemampuan guru yang tidak optimal dalam melakukan pengembangan. Pendapat tersebut tidak hanya keluar dari pemahaman siswa akan tetapi dari guru-guru tersebut pada saat melakukan persiapan pembelajaran. Terkadang ada anggapan bahwa mengajar sejarah itu terlalu mudah hanya tinggal membaca buku yang sama dengan siswa kemudian dijelaskan, padahal hal tersebut keliru. 
Menurut Hasan (2012: 74) permasalahan utama pendidikan sejarah adalah kenyataan bahwa orang lebih memperhatikan materi dan disiplin sejarah dibandingkan dengan kepentingan peserta didik. Beberapa Kenyataan yang teerdapat dalam pembelajaran sejarah ialah pemahaman yang keliru lainnya pada pembelajaran sejarah dimana menfokuskan pada pemahaman materi sebagai bekal siswa dalam memenuhi kebutuhan siswa. Padahal selain materi ada hal yang lebih penting yaitu perubahan kepribadian dan pola pikir siswa ketika dihadapkan kepada suatu masalah baik dalam pembelajaran maupun dalam kehidupan lingkungannya.

Pembelajaran sejarah yang baik adalah pembelajaran yang mampu menumbuhkan kemampuan siswa melakukan konstruksi kondisi masa sekarang dengan mengkaitkan atau melihat masa masa lalu yang menjadi basis topik pembelajaran sejarah. Kemampuan melakukan konstruksi ini harus dikemukakan secara kuat agar pembelajaran tidak terjerumus dalam pembelajaran yang bersifat konservatif. Kontekstualitas sejarah harus kuat mengemuka dan berbasis pada pengalaman pribadi para siswa. Sehingga siswa sebagai subjek dari pembelajaran bisa dan mampu mengamalkan apa yang dipelajari pada saat proses pembelajaran. belajar itu tidak hanya di kelas setelah itu kemudian ditinggalkan akan tetapi bisa diamalkan dalam kehidupan sehari-harinya.

Kurikulum 2013 dirancang untuk memperkuat kompetensi peserta didik dari sisi pengetahuan, keterampilan, dan sikap secara utuh. Keutuhan tersebut menjadi dasar dalam perumusan kompetensi dasar tiap mata pelajaran, sehingga kompetensi dasar tiap mata pelajaran mencakup kompetensi dasar kelompok sikap, kompetensi dasar kelompok pengetahuan, dan kompetensi dasar kelompok keterampilan.

Pengembangan Kurikulum 2013 merupakan langkah lanjutan Pengembangan Kurikulum Berbasis Kompetensi yang telah dirintis pada tahun 2004 dan KTSP 2006 yang mencakup kompetensi sikap, pengetahuan, dan keterampilan secara terpadu (Kemdikbud, Rasional Kurikulum, 2013). Kurikulum 2013 menekankan pada dimensi pedagogik modern dalam pembelajaran, yaitu menggunakan pendekatan ilmiah (Shoimin, 2014: 166).

Menurut Endjat Djaenuderajat (Direktur Sejarah dan Nilai Budaya Kementerian Pendidikan dan Budaya) mengemukakan :

"Pada pelaksanaan Kurikulum 2013,pelajaran Sejarah dibagi dua, sejarah umum yang dipelajari semua siswa dan sejarah peminatan. Materi Sejarah Lokal bisa dikembangkan di sejarah peminatan." (Tribunnews, 2013)

Untuk menerapkan konsep kesamaan antara SMA dan SMK maka dikembangkan kurikulum pendidikan menengah yang terdiri atas kelompok mata pelajaran wajib dan mata pelajaran pilihan. Mata pelajaran wajib sebanyak 9 (sembilan) ata pelajaran dengan beban belajar 18 jam per minggu. Konten kurikulum (Kompetensi Inti/KI dan KD) dan kemasan konten serta label konten (mata pelajaran) untuk mata pelajaran wajib bagi SMA dan SMK adalah sama. Struktur ini menempatkan prinsip bahwa peserta didik adalah subjek dalam belajar dan mereka memiliki hak untuk memilih sesuai dengan minatnya. Kompetensi dasar mata pelajaran wajib memberikan kemampuan dasar yang sama bagi tamatan Pendidikan Menengah antara mereka yang belajar di SMA dan SMK (Kemdikbud, 2012: 16).

Bagi mereka yang memilih SMA tersedia pilihan kelompok peminatan (sebagai ganti jurusan) dan pilihan antar kelompok peminatan dan bebas. Nama kelompok peminatan digunakan karena memiliki keterbukaan untuk belajar di luar kelompok tersebut sedangkan nama jurusan memiliki konotasi terbatas pada apa yang tersedia pada jurusan tersebut dan tidak boleh mengambil mata pelajaran di luar jurusan.

Struktur kelompok peminatan akademik memberikan keleluasaan bagi peserta didik sebagai subjek tetapi juga berdasarkan pandangan bahwa semua disiplin ilmu adalah sama dalam kedudukannya. Nama kelompok minat diubah dari IPA, IPS, dan Bahasa menjadi Matematika dan Sains, Sosial, serta Bahasa. Nama-nama ini tidak diartikan sebagai nama kelompok disiplin ilmu karena adanya berbagai pertentangan filosofis pengelompokan disiplin ilmu. Berdasarkan filosofi rekonstruksi sosial maka nama organisasi kurikulum tidak terikat

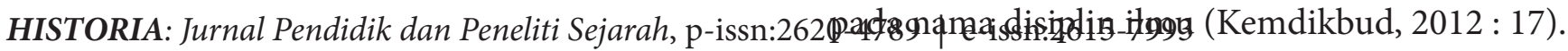




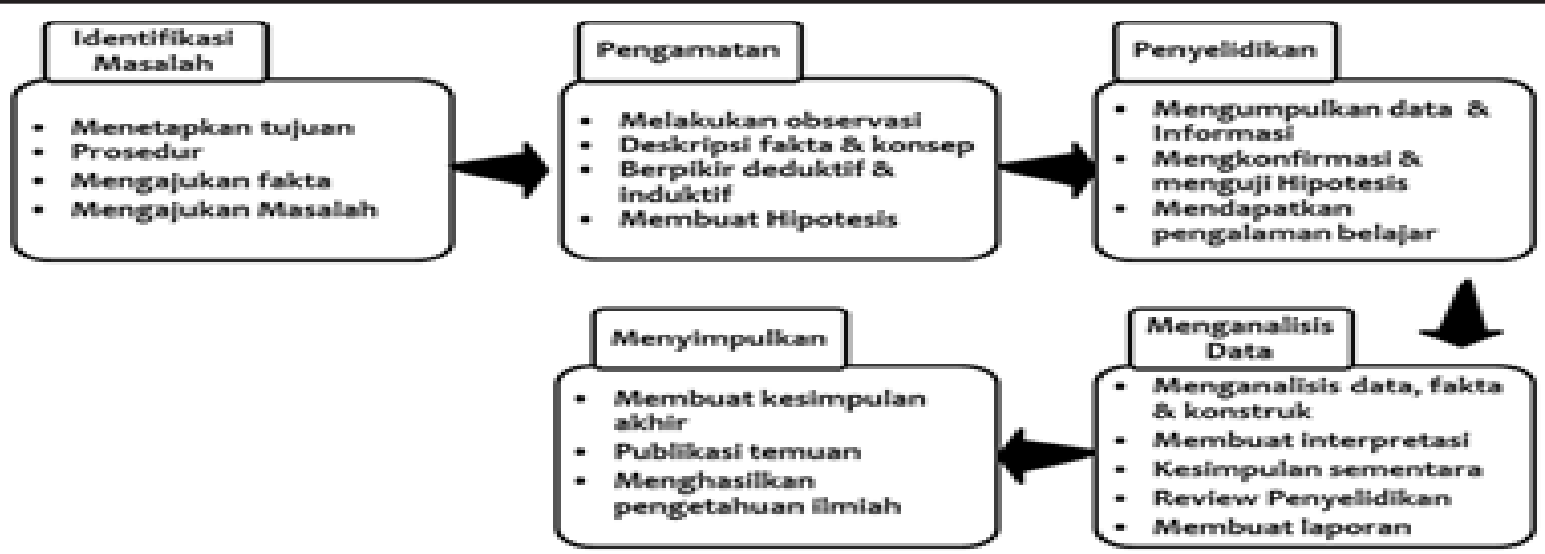

Bagan 3.1. Pendekatan Ilmiah dalam Pembelajaran. sumber : Kemdikbud

\section{Pendekatan Saintifik dalam Sejarah Lokal di Banten)}

Karakteristik pembelajaran Kurikulum 2013 meliputi, pendekatan tematik integratif, pendekatan saintifik, penilaian otentik, pendidikan karakter berbasis budaya lokal. Kemendikbud (2013) menjelaskan bahwa penggunaan pendekatan saintifik dimaksudkan untuk memberikan pemahaman kepada peserta didik dalam mengenal dan memahami berbagai materi menggunakan pendekatan ilmiah. Pendekatan saintifik menurut Kemendikbud adalah pendekatan yang digunakan dalam pembelajaran untuk mendorong peserta didik agar melakukan keterampilan mengamati (untuk mengidentifikasi hal-hal yang ingin diketahui), merumuskan pertanyaan (dan merumuskan hipotesis), mencoba/mengumpulkan data (informasi) dengan berbagai teknik, mengasosiasi/ menganalisis/mengolah data (informasi) dan menarik kesimpulan serta mengkomunikasikan

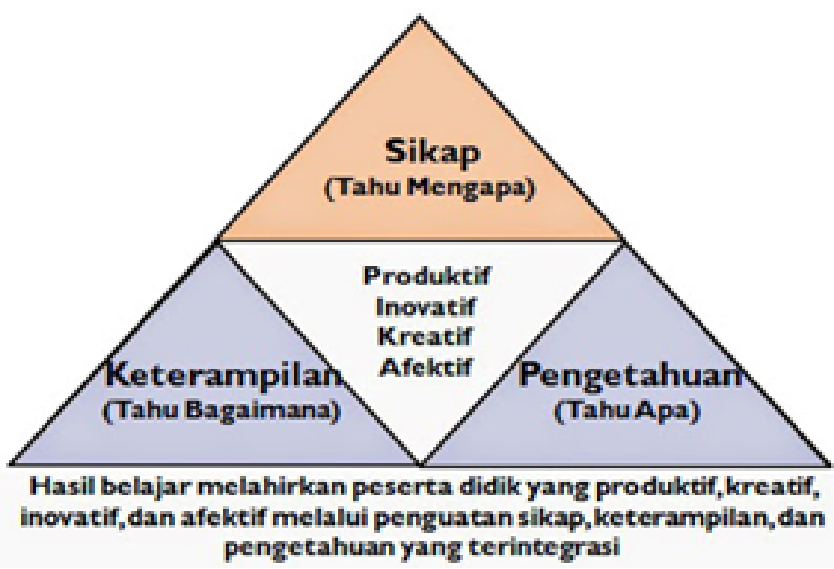

Bagan 3.2. Proses Pembelajaran Integratif pendekatan saintifik (Kemdiknas) hasil yang terdiridari kesimpulan untuk memperoleh pengetahuan, keterampilan dan sikap. Langkahlangkah tersebut dapat dilanjutkan dengan kegiatan mencipta. Hal Ini sesuai dengan permendikbud No. 65 Tahun 2013 tentang Standar Proses Pendidikan Dasar dan Menengah telah mengisyaratkan tentang perlunya proses pembelajaran yang dipandu dengan kaidah-kaidah pendekatan ilmiah (Sudrajat, 2013). Tujuan pendekatan saintifik membuat siswa berpikir lebih kritis, mampu mengkomunikasikan secara sistematis dan metodologis, mempunyai dasar alasan yang dapat dipertanggungjawabkan.

Model ini juga tercakup penemuan makna (meanings), organisasi, dan struktur dari ide atau gagasan, sehingga secara bertahap siswa belajar bagaimana mengorganisasikan dan melakukan penelitian. Pembelajaran berbasis keterampilan proses sains menekankan pada kemampuan peserta didik dalam menemukan sendiri (discover) pengetahuan yang didasarkan atas pengalaman belajar, hukum-hukum, prinsip-prinsip dan generalisasi, sehingga lebih memberikan kesempatan bagi berkembangnya keterampilan berpikir tingkat tinggi. Dengan demikian, peserta didik lebih diberdayakan sebagai subjek belajar yang harus berperan aktif dalam memburu informasi dari berbagai sumber belajar, dan guru lebih berperan sebagai organisator dan fasilitator pembelajaran.

Penerapan pendekatan saintifik dapat dilakukan dalam konten materi sejarah lokal Banten tentang gerakan sosial Kyai dan Petani melawan pemerintah Hindia Belanda. Menurut Supardan (2004:262) pembelajaran sejarah lokal, perlu diperkenalkan pada siswa untuk mengenali identitas kelokalannya 
maupun menghargai identitas etnis/daerah lain yang ada di Indonesia dengan mempertimbangkan azas belajar dan tahap perkembangan siswa. Pemerintah pusat dan daerah, guru-guru sejarah dilapangan harus berusaha sekuat-kuatnya untuk mendorong terlaksananya pembelajaran sejarah lokal disekolah-sekolah.

Dalam kurikulum sejarah, dapat dikembangkan dengan menggunakan lingkungan terdekat siswa sebagai sumber materi sejarah, baik dalam bentuk peninggalan-peninggalan fisik maupun peristiwaperistiwa lokal yang terjadi daerah di mana siswa tinggal (Mulyana, 2007:234). Dengan cara seperti ini siswa dapat melihat realitas yang ada di sekelilingnya. Siswa belajar sejarah bukan hanya belajar masa lalu yang jauh dari kehidupannya, tetapi dapat pula belajar sejarah dari realitas yang ia lihat, dengan cara begini belajar sejarah akan lebih bermakna.

Dengan mengoptimalkan pembelajaran sejarah lokal diharapkan nilai-nilai atau kearifan lokal yang menjadi identitas suatu daerah tetap lestari. Kondisi pembelajaran sejarah seperti inilah yang sangat diharapkan. Penyeleksian materi, penggunaan metode dan media, dan sistem evaluasi diserahkan sepenuhnya kepada pertimbangan guru. Dengan mengacu pada standar yang ditetapkan pemerintah pusat, guru dan sekolah dapat mengembangkan materi, metode dan media pembelajaran sendiri, sehingga dalam hal ini guru sejarah dapat mengembangkan materi pembelajaran sejarah lokal dalam proses pembelajarannya. Mengenai penting posisi materi sejarah lokal dan pembelajaran sejarah diungkapkan Hasan (2012:122), bahwa:

"Posisi materi sejarah lokal dalam kurikulum dianggap penting karena pendidikan harus dimulai dari lingkungan terdekat dan peserta didik harus menjadi dirinya sebagai anggota masyarakat terdekat. Oleh karena itu dalam posisi materi sejarah keluarga, desa, kelurahan, kecamatan dan seterusnya menjadi penting karena ia hidup di lingkungan-lingkungan tersebut sampai kepada sejarah bangsa di mana ia adalah sebagai warganya”.

Dalam posisi ini maka sejarah lokal akan memegang posisi utama karena berkenaan dengan lingkungan terdekat dan budaya peserta didik.
Dengan begitu, maka materi sejarah lokal menjadi dasar bagi pengembangan jati diri pribadi, budaya dan sosial peserta didik. Keterkaitan dan penafsiran materi sejarah lokal jangan sampai menimbulkan konflik dengan kepentingan sejarah nasional dan upaya membangun rasa persatuan, perasaan kebangsaan, dan kerjasama antar daerah dalam membangun kehidupan kebangsaan yang sehat, cinta damai, toleransi, penuh dinamika, kemampuan berkompetisi dan berkomunikasi. Selain itu, materi sejarah lokal tidak hanya sebagai sumber semata tetapi juga menjadi objek studi sejarah peserta didik.

Dalam kesempatan inilah mereka belajar mengembangkan wawasan, pemahaman, dan ketrampilan sejarah. Mereka dapat berhubungan langsung dengan sumber asli dan mengkaji sumber asli dalam suatu proses penelitian sejarah. Proses penyeleksian sejarah lokal sebagai bahan dan materi pembelajaran sejarah haruslah dilakukan secara selektif, sebab harus diakui sebagian besar sejarah lokal masih belum diteliti secara ilmiah oleh para sejarawan, sehingga guru harus berhati-hati menggunakan sumber sejarah lokal. Terlebih lagi, sumber-sumber sejarah lokal masih sangat sulit didapatkan, sehingga hal tersebut menjadi tantangan bagi sejarawan dan guru dalam mengembangkan pembelajaran sejarah lokal dalam keterbatasan sumber tersebut.

Gerakan Sosial perlawanan kyai dan petani di Banten merupakan salah satu dari sekian banyak peristiwa perlawanan masyarakat terhadap pemerintahan kolonial di Banten. Terdapat beberapa peristiwa lokal yang melibatkan peran Kyai dan Petani sebagai aktor utama dalam gerakan tersebut. Pertama, pergolakan di Serang tahun 1850: Gerakan Nativsme Haji Wachia. Latar belakang perlawanan didasari potensi adanya pergeseran di kalangan elite penguasa tradisional akibat adanya kompetisi dalam birokrasi di Serang. Marihandono dan juwono (2014: 167) dalam karyanya "Banten: sumber potensi heroisme di nusantara mengemukakan :

"Perlawanan Wachia ini memiliki latar belakang kebijakan politik kolonial yang kompleks di bidang politik, ekonomi, sosial, yang meskipun saling terpisah, pada kenyataannya menunjukan keterkaitan yang erat. Ketidakpuasan Jayakerta terhadap kebijakan politik administratif kolonial dengan mudah bisa mendapatkan

HISTORIA: Jurnal Pendidik dan Peneliti Sejarah, p-issn:2620-4789 | e-issn:2615-7993 
respon dari masyarakat termasuk elite informal karena ketidakpuasan mereka terhadap terhadap kebijakan sosial ekonomi rezim kolonial, termasuk perubahan dalam hal eksploitasi agrarianya. Begitu juga dengan simbol perlawanan terhadap kekuatan asing yang melambangkan kekafiran tetap menjadi fondasi ideologis yang kuat untuk menyatukan kelompok pemberontak yang berbeda latar belakangnya".

Kedua, gerakan sosial messianistik dalam Pemberontakan petani Banten 1888 atau masyarakat Banten lebih mengenalnya sebagai peristiwa Geger Cilegon. Peristiwa Geger Cilegon tahun 1888 dalam buku "Catatan Masa Lalu Banten" karya Michrob Halwany dan Mudjahid Chudari (2011 : 204) dikemukakan :

"Perlawanan bersenjata yang paling menonjol di Banten pada abad ke-19 adalah peristiwa yang dikenal dengan "Geger Cilegon", pada tanggal 9 Juli 1888 yang dipimpin oleh para ulama. Dalam setiap pengajian/dzikiran yang diadakan di rumah-rumah atau pun di masjid, para ulama itu selalu menanamkan semangat jihad menentang penjajah kepada masyarakat. Melalui pesantren-pesantren, para tokoh itu dengan mudah melancarkan taktik perjuangan menentang pemerintahan kolonial. Gerakan itu antara lain dipimpin oleh Haji Abdul Karim, Haji Tubagus Ismail, Haji Marjuki, dan Haji Wasid".

Latar belakang peristiwa ini karena terjadinya krisis kepercayaan masyarakat banten terhadap pemerintahan Hindia Belanda saat itu. Sartono Kartodirjo (1984) mengemukakan :

"Pemberontakan yang banyak terjadi di Banten karena adanya faktor-faktor tertentu adanya keresahan sosial dapat dicontohkan terjadinya disintegrasi tatanan tradisional karena semakin memburuknya system politik dan tumbuhnya kebencian religius terhadap penguasapenguasa asing, sehingga dapat memunculkan pemberontakan-pemberontakan pada abad 19. Aspek politik yang paling menonjol dalam pemberontakan tersebut karena kebencian rakyat terhadap pamongpraja dan perlawanan

Tabel 3.1. Pokok Bahasan dan Isu Sosial Kontemporer

\begin{tabular}{|c|c|c|c|c|}
\hline No & $\begin{array}{l}\text { Pokok Bahasan dalam } \\
\text { Kurikulum }\end{array}$ & $\begin{array}{l}\text { Konsep atau teori yang } \\
\text { digali }\end{array}$ & $\begin{array}{l}\text { Pertanyaan-pertanyaan kritis model ways of } \\
\text { knowing Habermas }\end{array}$ & Isu sosial Kontemporer \\
\hline 1 & $\begin{array}{lll}\text { Kerajaan } & \text { Islam } & \text { di } \\
\text { Indonesia } & & \end{array}$ & $\begin{array}{l}\text { Struktur Birokrasi dan } \\
\text { Masyarakat Banten }\end{array}$ & $\begin{array}{l}\text { Mengapa kesultanan Banten dipindahkan } \\
\text { dari Banten Girang ke Surosowan? } \\
\text { 2. Bagaimana peran Sultan, Qadhi, Wazir, } \\
\text { Kyai/Ulama, dan Jawara pada kesultanan } \\
\text { Banten? }\end{array}$ & $\begin{array}{ll}\text { - } & \text { Kemajuan } \\
& \text { perekonomian } \\
\text { - } & \text { Kedudukan sosial dan } \\
\text { peran }\end{array}$ \\
\hline 2 & $\begin{array}{l}\text { Perlawanan rakyat } \\
\text { Indonesia terhadap } \\
\text { pemerintah kolonial }\end{array}$ & $\begin{array}{l}\text { Kapitalisme, } \\
\text { Sosialisme, Gerakan } \\
\text { Sosial, Masyarakat } \\
\text { Agraris, Messianistik, } \\
\text { Millenarisme, } \\
\text { Nativisme, Deprivasi } \\
\text { relatif. }\end{array}$ & $\begin{array}{l}\text { 1. Bagaimana dampak positif dan negatif } \\
\text { sistem kapitalisme kolonial di Banten? } \\
\text { 2. Mengapa muncul gerakan sosial melawan } \\
\text { pemerintah kolonial di Banten? } \\
\text { 3. Mengapa Kyai/petani berperan penting } \\
\text { dalam gerakan sosial di Banten? }\end{array}$ & $\begin{array}{lcr}\text { Kesenjangan } & \text { sosial antara } \\
\text { kelompok agraris } & \text { dan } \\
\text { kapitalis, Struktur Birokrasi, }\end{array}$ \\
\hline 3 & Masa Revolusi Indonesia & $\begin{array}{lr}\text { Revolusi } & \text { fisik, } \\
\text { Konfrensi, } & \text { Agresi } \\
\text { Militer } & \end{array}$ & $\begin{array}{l}\text { 1. Mengapa Belanda ingin kembali berkuasa } \\
\text { di Indonesia setelah proklamasi ? } \\
\text { 2. Mengapa terjadi perlawanan terhadap } \\
\text { Belanda oleh masyarakat Banten setelah } \\
\text { kemerdekaan? }\end{array}$ & \\
\hline
\end{tabular}


terhadap sewa tanah yang akan diterapkan oleh pemerintah kolonial di agen- agennya. Langkanya uang dan rendahnya hasil-hasil petani memunculkan pemberontakan untuk menyampaikan ketidakpuasan dan dendam mereka. Pemberontakan ini juga karena diperkuat karena adanya kekuasaan para orangorang kafir atau bisa disebut penganut milenari atau mesianik. Pemberontakan-pemberontakan tersebut bersifat revolusioner yang mempunyai tujuan untuk menghancurkan birokrasi yang korup dan menumbangkan sistem pemerintahan yang dibangun oleh penguasa asing. Pemberontakan tersebut juga dapat dipandang untuk merebut kekuasaan politik yang dikuasai oleh pamongpraja kolonial, akan tetapi dalam pemberontakan tersebut pihak pamongpraja kolonial yang selalu menang karena golongan-golongan yang memberontak lemah dalam bidang organisasi".

Ketiga, Perjuangan K.H. Achmad Chatib dan K.H. Syam'un pada masa Revolusi fisik di Banten tahun 1945-1949. Latar belakang perjuangan adalah keinginan pasca kemerdekaan Indonesia untuk mempertahankan wilayah Indonesia khususnya Banten dari tentara NICA Belanda. Sesaat setelah berita Proklamasi Kemerdekaan menyebar, terjadi perubahan-perubahan sosial-politik diberbagai sudut Indonesia, salah satunya juga terjadi di Banten. Kelompok sosial seperti ulama, pemuda, dan jawara bersatu padu dalam merebut kekuasaan dari pemerintah Jepang atau Dai Nippon yang saat itu dibawah Residen (Shuchokan) Banten. Kelompok sosial ini melakukan koalisi dan berhasil merebut kekuasaan ke tangan kaum pribumi seutuhnya. Kemudian, terbentuklah Pemerintahan daerah Banten yang baru bernama Pemerintahan Daerah Karesidenan Banten yang dipimpin oleh K.H. Tb. Achmad Chatib sebagai Residen.

Pemerintahan ini didukung oleh elemen pemuda, ulama, intelektual pribumi, dan angkatan bersenjata. Lalu, untuk menjaga keamanan di daerah Banten dibentuklah Badan Keamanan Rakyat (BKR) Karesidenan Banten yang dipimpin oleh K.H Sjam'un. Pengambil alihan dari Jepang tidak banyak mengalami beberapa kendala.
Peran kaum ulama sangat penting pada fase AMB II ini. Mereka sangat dipercaya rakyat, mereka juga memberikan contoh ketabahan dalam menghadapi kesulitan. K.H. Tb. Achmad Chatib yang juga seorang ulama banyak memberi pengaruh dan teladannya. Keyakinan K.H. Tb. Achmad Chatib didasarkan pada pengetahuanya terhadap rakyat Banten yang taat pada agama dan patuh pada para ulama yang menjadi pemimpin mereka. Pendiriannya yang kuat dalam berjuang, ia pantang mundur ketika sebagian pegawai pemerintahannya memihak kepada Belanda, seperti ucapannya berikut ini:

"Seandainya semua rakyat Banten mengikuti kepada Belanda, baik berilah saya sebuah senjata untuk sekedar penjagaan diri saya dari gangguan binatang buas. Saya lebih senang menjadi orang hutan saja dari pada dijajah kembali oleh Belanda. Tetapi saya yakin bahwa tidak akan terjadi sedemikan". (Majalah Merdeka, Th II, No.14, 2 April 1949: 7, dalam Suharto, 2001: 204).

Beberapa materi sejarah lokal tersebut dapat diintegrasikan ke dalam pembelajaran dalam pendekatan saintifik. Tahapan dalam pendekatan saintifik yang pertama dilakukan ialah guru sebagai fasilitator dalam pembelajaran menyajikan materi sejarah lokal melalui video atau film yang terkait materi, guru juga bisa menampilkan gambargambar yang juga terkait dengan materi. Selain itu pengamatan juga dapat dilakukan pada saat guru melakukan simulasi. Hal ini berkaitan dengan tahap pengamatan.

Kegiatan mengamati dalam pembelajaran sebagaimana disampaikan dalam Permendikbud Nomor 81a, hendaklah guru membuka secara luas dan bervariasi kesempatan peserta didik untuk melakukan pengamatan melalui kegiatan : melihat, menyimak, mendengar, dan membaca. Guru memfasilitasi peserta didik untuk melakukan pengamatan, melatih mereka untuk memperhatikan (melihat, membaca, mendengar) hal yang penting dari suatu benda atau objek. Adapun kompetensi yang diharapkan adalah melatih kesungguhan, ketelitian, dan mencari informasi. 
Pengamatan dapat dilaksanakan oleh para siswa dengan bimbingan guru untuk memperoleh informasi awal yang berkaitan dengan peristiwa sejarah lokal tersebut. Douch dalam Mulyana dan Gunawan (2007: 1) mengemukakan :

"Dalam pembelajaran sejarah, hendaknya siswa dapat melihat langsung kehidupan nyata, bukan materi pelajaran yang jauh dari realitas. Bahkan belajar yang baik dapat bersumber dari pengalaman siswa dengan lingkungannya merupakan sumber belajar yang berharga bagi terjadinya proses pembelajaran di kelas".

Lingkungan terdekat yang bisa dijadikan sumber belajar ialah perpustakaan dan museum sebagai sarana belajar. Perpustakaan merupakan sarana bagi siswa untuk memperoleh informasi sebanyak-banyaknya mengenai peristiwa gerakan sosial di Banten. Pengamatan dilakukan agar menumbuhkan rasa ingin tahu (sense of knowing) siswa mengenai materi sejarah lokal.

Tahap selanjutnya merupakan kegiatan bertanya dan mempersiapkan pertanyaan yang berkaitan dengan peristiwa sejarah lokal. Kegiatan "menanya" dalam kegiatan pembelajaran sebagaimana disampaikan dalam Permendikbud Nomor 81a Tahun 2013, adalah mengajukan pertanyaan tentang informasi yang tidak dipahami dari apa yang diamati atau pertanyaan untuk mendapatkan informasi tambahan tentang apa yang diamati (dimulai dari pertanyaan faktual sampai ke pertanyaan yang bersifat hipotetik). Adapun kompetensi yang diharapkan dalam kegiatan ini adalah mengembangkan kreativitas, rasa ingin tahu, kemampuan merumuskan pertanyaan untuk membentuk pikiran kritis yang perlu untuk hidup cerdas dan belajar sepanjang hayat. Pada kegiatan pembelajaran ini, siswa melakukan pembelajaran bertanya (Hosnan, 2014:49)

Pada tahap ini, guru sejarah dapat mengangkat isu yang berasal dari dokumen kurikulum sejarah kemudian dihubungkan dengan materi sejarah lokal yang sedang dikaji oleh siswa. Supriatna (2007: 123) mengemukakan :

"Pokok bahasan seperti kerajaan Islam, perlawanan daerah terhadap pemerintah kolonial, pergerakan nasional, sistem ekonomi Hindia Belanda, dan masa revolusi kemerdekaan merupakan isu yang menarik untuk kajian sekaligus pokok bahasan yang dapat dihubungkan dengan masalah sosial kontemporer melalui "jembatan penghubung" berupa konsep/teori serta pertanyaanpertanyaan kritis model ways of knowing dari Habermas"

Pertanyaan yang disusun oleh guru untuk kemudian dikembangkan oleh siswa sehingga muncul permasalahan yang nantinya harus dijawab oleh siswa. Tahap ini juga akan menumbuhkan sikap berfikir kritis dan historis siswa karena siswa diarahkan untuk menyelesaikan permasalahan dalam pertanyaan yang mereka susun sendiri (Problem Solving).

Tahap berikutnya adalah mencoba (experimenting) melakukan pengumpulan data/ sumber sejarah untuk melakukan rekonstruksi. Dalam Permendikbud Nomor 81a Tahun 2013, aktivitas mengumpulkan informasi dilakukan melalui eksperimen, membaca sumber lain selain buku teks, mengamati objek/kejadian/ aktivitas wawancara dengan narasumber, dan sebagainya. Adapun kompetensi yang diharapkan adalah mengembangkan sikap teliti, jujur, sopan, menghargai pendapat orang lain, kemampuan berkomunikasi, menerapkan kemampuan mengumpulkan informasi melalui berbagai cara yang dipelajari, mengembangkan kebiasaan belajar dan belajar sepanjang hayat (Hosnan, 2014:57). Dalam hal ini, sejarah lokal yang dijadikan kajian ialah gerakan sosial Kyai dan petani di Banten. Pengumpulan data/sumber dalam metode sejarah ialah heuristik (Sjamsuddin, $2007: 86$ ).

Heuristikyang dalambahasa Jerman disebutjuga dengan Quellenkunde merupakan sebuah kegiatan awal mencari sumber-sumber untuk mendapatkan data-data atau materi sejarah atau evidensi sejarah (Sjamsuddin, 2007: 86). Pada tahap ini siswa berusaha mencari sumber-sumber yang relevan bagi permasalahan yang sedang dikaji. Menurut Helius Sjamsuddin (1996: 730) yang dimaksud dengan sumber sejarah adalah segala sesuatu yang langsung atau tidak langsung menceritakan kepada kita, tentang sesuatu kenyataan atau kegiatan di masa lalu. Sumber sejarah berupa bahan-bahan sejarah yang memuat bukti-bukti aktifitas manusia dimasa 
lampau yang berbentuk tulisan atau cerita. Sumber tertulis berupa buku dan artikel yang berhubungan dengan permasalahan yang dikaji dan juga ditambah dengan sumber lisan dengan menggunakan teknik wawancara kepada nara sumber yang menjadi pelaku dan juga mengetahui tentang Gerakan Sosial Kyai dan Petani di Banten. Sumber sejarah lokal berupa literatur bisa didapatkan di Perpustakaan Daerah dan museum. Sumber lisan dapat diperoleh dengan wawancara kepada Tokoh agama, sejarawan, atau instansi pemerintah terkait.

Tahap selanjutnya adalah aktivitas menalar (Associating) yang dilakukan siswa terhadap sumber sejarah lokal yang telah diperoleh. Istilah "menalar" dalam kerangka proses pembelajaran dengan pendekatan ilmiah yang dianut dalam kurikulum 2013 untuk mengembangkan bahwa guru dan peserta didik merupakan pelaku aktif. Titik tekannya tentu dalam banyak hal dan situasi peserta didik harus lebih aktif daripada guru. Penalaran adalah proses berfikir yang logis dan sistematis atas fakta-fakta empiris yang dapat diobservasi untuk memperoleh simpulan berupa pengetahuan. Penalaran dimaksud merupakan penalaran ilmiah, meski penakaran nonilmiah tidak selalu tidak bermanfaat (Hosnan, 2014: 67).

Dalam metode historis, tahap ini dikenal sebagai tahap kritik dan interpretasi. Siswa tidak lantas menerima begitu saja apa yang tercantum dan tertulis pada sumber-sumber itu. Langkah selanjutnya adalah siswa harus melakukan penyaringan secara kritis terhadap sumber yang diperoleh, terutama terhadap sumber-sumber primer, agar terjaring fakta yang menjadi pilihannya. Langkah-langkah inilah yang disebut kritik sumber, baik terhadap bahan materi (ekstern) sumber maupun terhadap substansi (isi) sumber. Dalam tahap ini data-data yang telah diperoleh berupa sumber tertulis maupun sumber lisan disaring dan dipilih untuk dinilai dan diselidiki kesesuaian sumber, keterkaitan dan keobjektifannya.

Setelah sumber sejarah lokal di kritisi, siswa menafsirkan atau memberi makna kepada fakta-fakta (facts) atau bukti-bukti sejarah lokal (evidences). Penalaran/penafsiran diperlukan karena pada dasarnya bukti-bukti sejarah (evidences) dan fakta-fakta sebagai saksi-saksi sejarah tidak dapat berbicara sendiri mengenai apa yang disaksikannya dari realitas masa lampau. Interpretasi merupakan proses pemberian penafsiran terhadap fakta yang telah dikumpulkan. Siswa mulai menyusun dan merangkai fakta-fakta sejarah yang didasarkan pada sumber sejarah yang telah dikritik sebelumnya. Dalam upaya rekonstruksi sejarah masa lampau pertama-tama interpretasi memiliki makna memberikan kembali relasi antar fakta-fakta. Tahapan tersebut ialah mencari dan membuktikan adanya relasi antara fakta yang satu dengan lainnya, sehingga terbentuk satu rangkaian makna yang faktual dan logis tentang bagaimana Gerakan Sosial Kyai dan Petani di Banten.

Terakhirmerupakan tahapmembangunjaringan (networking) kemudian mengkomunikasikan hasil kajian sejarah lokal. Kegiatan ini dapat dilakukan melalui menuliskan atau menceritakan apa yang ditemukan dalam kegiatan mencari informasi, mengasosiasikan dan menemukan pola. Hasil tersebut disampaikan di kelas dan dinilai oleh guru sebagai hasil belajar peserta didik atau kelompok peserta didik tersebut. Kegiatan "mengomunikasikan" dalam kegiatan pembelajaran sebagaimana disampaikan dalam Permendikbud Nomor 81a Tahun 2013, adalah menyampaikan hasil pengamatan, kesimpulan berdasarkan hasil analisis secara lisan, tertulis, atau media lainnya. Dalam kegiatan mengomunikasikan peserta didik diharapkan sudah dapat mempresentasikan hasil temuannya untuk ditampilkan di depan khalayak ramai sehingga rasa berani memberikan komentar, saran, atau perbaikan mengenai apa saja dipresentasikan oleh rekannya (Hosnan, 2014:76).

Pada tahap ini peserta didik di harapkan mampu mengkomunikasikan dengan kelompok lain tentang informasi apa yang sudah di olah dalam kelompoknya. Disinilah inti dari saintifik yaitu peserta didik diharapkan untuk saling bertukar informasi dengan kelompok lain, dipajang di "Majalah Dinding" atau dimuat di surat kabar atau majalah sekolah. Sehingga akan tercipta kondisi peserta didik yang aktif, dan menjadikan peserta didik menjadi subjek belajar.

\section{SIMPULAN}

Pendidikan Karakter Berbasis Budaya Lokal, juga diterapkan pada kurikulum 2013.

HISTORIA: Jurnal Pendidik dan Peneliti Sejarah, p-issn:2620-4789 | e-issn:2615-7993 
Pendidikan yang relevan harus menghargai dan mengembangkan keutamaan lokal. Nilai-nilai yang terdapat di dalam sebuah masyarakat dapat menjadi panduan bagi sekolah dalam mendesain kurikulum pendidikan karakter. Sekolah mesti memahami kultur dan budaya daerah setempat sehingga dapat menanamkan berbagai macam nilai kearifan lokal. Budaya lokal yang tertanam dalam setiap individu nantinya akan dianggap sebagai warisan kebudayaan masyarakat.

Tugas guru selain mendidik siswa juga melakukan penilaian atas aktivitas yang dilakukan siswa. Pembelajaran yang menyenangkan akan mengaktifkan siswa untuk melakukan semua kegiatan yang telah direncanakan oleh guru. Selain mengaktifkan siswa, guru juga harus melakukan penilaian untuk mengukur kemampuankemampuan siswa baik kognitif, sikap spiritual, sikap sosial, maupun ranah keterampilannya. Penilaian otentik akan sangat membantu guru untuk memberikan penilaian selama proses belajar. Permendikbud No. 66 tahun 2013 menjelaskan bahwa yang dimaksud dengan penilaian otentik adalah penilaian yang dilakukan secara komprehensif untuk menilai masukan (input), proses, dan keluaran (output) pembelajaran.

\section{REFERENSI}

Abdullah, T. (2004). Di sekitar Gugatan Terhadap Pelajaran dan Buku Sejarah. Historia Jurnal Pendidikan Sejarah No 9, V, 30.

Arif, M. (2008). Desain Pembelajaran Sejarah berbasis Hiperteks.dalam Sejarah dalam Keberagaman (Penghormatan kepada Prof. Dr.Helius Sjamsuddin, Ph.D, M.A). Jurdik Sejarah UPI: Bandung.

Benjamin. (1991). A Student Guide to History. New York (USA): St. Martin Press Depdikbud. (2007). Kamus Besar Bahasa Indonesia. Jakarta: Depdikbud.

Carr, E.H. (1961). What Is History. New York: Penguin Book Djahiri, H.A.Kosasih. (1990). Menulusuri Dunia Afektif; Lab.PPKN UPI.

Carreterom, dkk (2002). Teaching History Through Textbook: Are Mexican an Spanish
Egan, K. (1979). Memory, Imagination and Learning: Connected by the Story. New York: Oxford University Press.

Hasan, S.H.. (1999) "Pendidikan Sejarah Untuk Membangun Manusia Baru Indonesia”, dalam Mimbar Pendidikan, Nomor 2 Tahun XVIII, Bandung IKIP Bandung, hlm.4-11.

Hasan, Said.H. (2012). Pendidikan Sejarah Indonesia : Isu dalam Ide dan Pembelajaran. Bandung : Rizqi Press

Hosnan. 2014. Pendekatan Saintifik dan Kontekstual dalam Pembelajaran Abad 21. Bogor: Ghalia Indonesia.

Isjoni. (2007). Pembelajaran Sejarah pada Satuan Pendidikan. Alfabeta: Bandung.

Kartodirjo, Sartono. (1984). Pemberontakan Petani Banten 1888. Jakarta : Pustaka Jaya.

Kemendikbud. (2012). Dokumen Kurikulum 2013.

Kemendikbud. (2013). Peraturan Menteri Pendidikan dan Kebudayaan Nomor 81A Tahun 2013 Tentang Implementasi Kurikulum 2013

Kemendikbud. (2013). Peraturan Menteri Pendidikan dan Kebudayaan Nomor 66 tahun 2013 Tentang Implementasi Kurikulum 2013

Marihandono, Djoko. Juwono, Harto. (2014). Banten: Sumber Potensi Heroisme di Nusantara. Serang : Disbudpar Prov. Banten

Michrob, Halwany. Chudari, Mujahid. (2011). Catatan Masa Lalu Banten. Serang : Saudara.

Mulyana, Agus dan Restu Gunawa. (2007). Sejarah Lokal Penulisan dan Pembelajaran di Sekolah. Bandung : Salamina Press.

Mulyasa. (2013). Pengembangan dan Pengimplementasian Kurikulum 2013. Bandung : PT Remaja Rosdakarya

Santosa, A.B dan Fauzi, W.I. (2017). The Application of Brain-Based Learning in Social Studies Textbook to Inculcate Multicultural Values. Advances in Social Science, Education and Humanities Research (ASSEHR), volume 147, 1st International Conference on Social Sciences Education "Multicultural Transformation in Education, SSocial Sciences and Wetland Environment" (ICSSE 2017)

Sharma, S.K. (2008). Teaching of History. Lotus Press (New Delhi, India) 
Shoimin, Aris. (2014). 68 Model Pembelajaran Inovatif dalam Kurikulum 2013. Yogyakarta: Ar-Ruzz Media.

Sjamsuddin, Helius. (2007). Metodologi Sejarah. Yogyakarta : Ombak.

Sudrajat, A. (2013). Pendekatan Saintifik/ Ilmiah dalam Proses Pembelajaran. Tersedia [Online] http// : akhmadsudrajat.wordpress. com/2013/07/18/pendekatan-saintifikilmiahdalam-proses-pembelajaran/ (18 Juni 2013)

Sugiyono. (2010). Metode penelitian Kuantitatif Kualitatif dan R \&D. Bandung: Alfabeta.

Suharto. (2001). Banten Masa Revolusi, 19451949 Proses Integrasi Dalam Negara Kesatuan Republik Indonesia. Disertasi FIB UI

Supardan, D. (2004). Pembelajaran Kesadaran Sejarah berbasis Pendekatan Multikultural dan Perspektif Sejarah Lokal, Nasional, Global dalam Integrasi Bangsa. Disertasi: SPS UPI Bandung
Supriadi, Dedi. (2000). Anatomi Buku Sekolah di Indonesia. Bandung : Adi Cita.

Supriatna, N. (2007). Konstruksi Pembelajaran Sejarah Kritis. Bandung : Historia Utama Press

Tribunnews. (2013). Sejarah Lokal Mendapat Tempat dalam Pendidikan. Tersedia [Online] http://wartakota.tribunnews.com/detil/ berita/164637/Sejarah-Lokal-MendapatTempat-dalam-Pendidikan $\quad(20$ September 2013)

Weiner, R.G. (2001). History: Teaching and Methode. Texas Tech University

Wineburg, S. (2007). Berpikir Historis: Memetakan Masa Depan, Mengajarkan Masa Lalu. Jakarta: Yaysan Obor Indonesia.

Wiriatmadja, Rochiati Wiriaatmadja. (2001). Pendidikan Sejarah di Inonesia Perpektif lokal, nasional dan global. Bandung: Historia Press Utama 